\title{
Overexpression of suppressor of IKBKE 1 is associated with vincristine resistance in colon cancer cells
}

\author{
CHUN-PENG ZHAO ${ }^{1}$, ZHONG-JIE XU ${ }^{2}$, QING GUO ${ }^{3}$, \\ YUN-XIAO LI ${ }^{2}$, XIANG-ZHENG GAO ${ }^{2}$ and YI-YOU PENG ${ }^{2}$ \\ Departments of ${ }^{1}$ Biochemistry and Molecular Biology, ${ }^{2}$ Life Science and Technology, and \\ ${ }^{3}$ College of Basic Medicine, Xinxiang Medical University, Xinxiang, Henan 453003, P.R. China
}

Received April 15, 2016; Accepted July 28, 2016

DOI: $10.3892 /$ br.2016.759

\begin{abstract}
In a previous study, the suppressor of IKBKE 1 expression level was confirmed to be higher in vincristine (VCR)-resistant HCT-8 (HCT-8/V) colon cancer cells than in non-VCR-resistant HCT-8 cells. In the current study, IKBKE 1 expression in VCR-resistant colon cancer cells was investigated further. HCT-8 and HCT-8/V human colon cancer cells were used, and polymerase chain reaction (PCR) primers were designed to amplify the $I K B K E 1$ gene. Fluorescence reverse transcription-quantitative PCR (RT-qPCR) was performed to detect differences in IKBKE 1 expression between sensitive and drug-resistant colon cancer cell lines. Western blotting was performed to further observe IKBKE 1 expression. Based on the RT-qPCR and western blot results, IKBKE 1 expression was observed to be markedly higher in the HCT-8/V cells, and this difference was significant $(\mathrm{P}<0.05)$. Thus, IKBKE 1 expression was identified to be associated with the resistance of colon cancer cells to VCR.
\end{abstract}

\section{Introduction}

As a result of economic development and lifestyle changes, the incidence of colorectal cancer (CRC) is increasing annually, causing serious harm to human life and health. CRC is the third most common malignancy worldwide (1) and chemotherapy is an important component of comprehensive CRC treatment (2). Drug-resistant cells have become an issue for the treatment of malignant tumor cells, such as CRC cells; $90 \%$ of cancer patient mortalities are associated with the drug resistance of tumors $(2,3)$. Therefore, understanding the occurrence and developmental mechanism of drug resistance

Correspondence to: Mr. Chun-Peng Zhao, Department of Biochemistry and Molecular Biology, Xinxiang Medical University, 601 Jinsui Avenue, Xinxiang, Henan 453003, P.R. China

E-mail: 1090069176@qq.com

Key words: colon cancer, drug resistance, HCT-8, suppressor of IKBKE 1, vincristine is a key issue in the treatment of malignant tumors. Tumor resistance mechanisms act at the molecular and cell biology levels, and include changes in drug targets, the repair of damaged cells, activation or inhibition of cell death signaling pathways, genetic mutations, deletions, gene amplification, abnormal DNA methylation and other epigenetic changes, and post-transcriptional regulation by microRNAs (4-6).

Vincristine (VCR) is the most commonly administered chemotherapeutic agent to treat CRC in clinical practice. VCR is a cell cycle-specific medication that binds to tubulin; it inhibits the assembly of microtubule structures and arrests mitosis at metaphase (7). Suppressor of IKBKE 1 suppresses inhibitor- $\kappa \mathrm{B}$ kinase $\varepsilon(\mathrm{IKK} \varepsilon)$, a necrosis factor $(\mathrm{NF})-\kappa \mathrm{B}$ modulator, via a non-canonical pathway (8). IKBKE 1 is known to interact with $\mathrm{IKK} \varepsilon$ and TANK binding kinase 1 to inhibit virus-triggered and toll-like receptor 3-triggered activation (9). Hsieh et al (10) demonstrated that miR-146a-5p is a novel chemokine (C-X-C motif) ligand 12 and IKBKE 1 inhibitor. Therefore, regulating miR-146a-5p expression in mesenchymal stem cells may improve the engraftment of transplanted mesenchymal stem cells that are homing to injured tissues (10).

In the previous study, IKBKE 1 demonstrated decreasing expression in HCT-8 VCR-resistant (HCT-8/V) colon cancer cells using next-generation sequencing (11); however, the function and mechanism of IKBKE 1 require further investigation. In the current study, the expression of IKBKE 1 was further verified by reverse transcription-quantitative polymerase chain reaction (RT-qPCR) and western blotting, and investigated their role in modulating VCR resistance. IKBKE 1 may present as a novel candidate target for gene therapy in VCR-resistant ovarian cancer.

\section{Materials and methods}

Cell lines and culture. The human colon cancer cell line, HCT- 8 was purchased from the Cell Bank of the Chinese Academy of Sciences (Shanghai, China) and HCT-8/V cells were generated according to our previous study (11). Cells were maintained in Dulbecco's modified Eagle's medium (Sigma-Aldrich, St. Louis, MO, USA) containing 10\% fetal calf serum (Zhejiang Tianhang Biotechnology Co., Ltd., Hangzhou, China), $100 \mu \mathrm{g} / \mathrm{ml}$ penicillin and $100 \mu \mathrm{g} / \mathrm{ml}$ streptomycin at 
$37^{\circ} \mathrm{C}$ in a $\mathrm{CO}_{2}$ incubator. The cells were subcultured every 2-3 days following treatment with $0.02 \%$ EDTA acid and $0.1 \%$ trypsin (Hangzhou Genom Biological Pharmaceutical Technology Co., Ltd., Hangzhou, China).

RNA extraction. A total of 50-100 mg sample was grinded with liquid nitrogen, and $1 \mathrm{ml}$ lysate (SinoGene Scientific Co., Ltd., Beijing, China) was added after samples were transferred to $1.5 \mathrm{ml}$ RNase-free centrifuge tubes. The blended mixture was supplemented with $200 \mu$ l chloroform and was vigorously shaken for $30 \mathrm{sec}$. Then, the mixture was centrifuged for $15 \mathrm{~min}$ at $12,000 \mathrm{x}$ g and $4^{\circ} \mathrm{C}$. The supernatant was separated in a $1.5 \mathrm{ml}$ RNase-free centrifuge tube and an equal volume of isopropanol was added. After centrifugation for $15 \mathrm{~min}$ at 12,000 x g and $4^{\circ} \mathrm{C}$, the supernatant was removed and the remaining solution was supplemented with $750 \mu 175 \%$ ethanol, and the mixture was centrifuged for $5 \mathrm{~min}$ at $12,000 \mathrm{x} \mathrm{g}$ and $4^{\circ} \mathrm{C}$. The supernatant was removed and $45 \mu \mathrm{l}$ diethylpyrocarbonate (DEPC) water was added to dissolve the RNA after drying with ethanol. The extracted RNA was used or stored at $-80^{\circ} \mathrm{C}$.

$R T-q P C R$. RT-qPCR was performed using a Custom RT-qPCR Gene Expression Assay kit (SinoGene Scientific Co., Ltd.) according to the manufacturer's instructions. The primers are presented in Table I (GAPDH served as an internal reference) and were synthesized by Shanghai Sangon Biological Engineering Technology Service Co., Ltd. (Shanghai, China). The volume of the reverse transcription (RT) system was $20 \mu \mathrm{l}$, including $10 \mu \mathrm{l}$ total RNA, $1 \mu \mathrm{l}$ Oligo(dT)18, $1 \mu \mathrm{l}$ RT enzyme, $1 \mu 110 \mathrm{mmol} / 1$ deoxynucleotides, $4 \mu 1$ 5X Reaction Buffer, $0.5 \mu \mathrm{l}$ ribonuclease inhibitor and DEPC water up to a volume of $20 \mu \mathrm{l}$. After centrifugation for $5 \mathrm{~min}$ at $12,000 \mathrm{x} \mathrm{g}$ and $4^{\circ} \mathrm{C}$, the mixture was incubated for $60 \mathrm{~min}$ at $37^{\circ} \mathrm{C}$ and for $10 \mathrm{~min}$ at $85^{\circ} \mathrm{C}$ to inactivate the reverse transcriptase. The qPCR system included 7.5 $\mu \mathrm{l}$ 2X SG Green qPCR Mix, $10 \mu \mathrm{M}$ primers $(0.25 \mu \mathrm{l}), 1 \mu \mathrm{l} \mathrm{cDNA}$, and DEPC water up to a volume of $20 \mu \mathrm{l}$. The PCR reaction conditions were as follows: Predegeneration for $10 \mathrm{~min}$ at $95^{\circ} \mathrm{C}$, followed by 45 cycles of $95^{\circ} \mathrm{C}(15 \mathrm{sec}), 60^{\circ} \mathrm{C}$ (15 sec), and $72^{\circ} \mathrm{C}(30 \mathrm{sec})$. The $\mathrm{Cq}$ value method $\left(2^{-\Delta \Delta \mathrm{Cq}}\right)$ was used to perform quantitative analysis (12).

Western blot analysis. Cellular proteins were extracted with Cell Lysis Buffer (Cell Signaling Technology, Danvers, MA, USA) containing $1 \mathrm{mM}$ phenylmethylsulfonyl fluoride. Equal quantities of protein $(0.05 \mu \mathrm{g})$ were fractionated by $7 \%$ sodium dodecyl sulphate polyacrylamide gel electrophoresis $(100 \mathrm{~V}$ for $30 \mathrm{~min}$ for concentration gel and $150 \mathrm{~V}$ for $80 \mathrm{~min}$ for separation gel) (13), transferred to a polyvinylidene difluoride membrane, and reacted with antibodies against IKBKE 1 (1;1,000 dilution; cat. no. B1310; Sigma-Aldrich), and $\beta$-actin (1;1,000 dilution cat. no. AC-74; Sigma-Aldrich). The band intensity was quantified using ImageJ software (version 1.47; National Institutes of Health, Bethesda, MD, USA) after normalization to the corresponding loading control.

Statistical analysis. All data were analyzed with SPSS 13.0 (SPSS, Inc., Chicago, IL, USA). Data are expressed as means \pm standard deviation. One-way analysis of variance and Student's t-tests were used for statistical analyses, and $\mathrm{P}<0.05$ was considered to indicate a statistically significant difference.
Table I. Primers used in the present study.

\begin{tabular}{ccc}
\hline & Sequence & Product \\
Primer & $\left(5^{\prime}-3^{\prime}\right)$ & length $(b p)$
\end{tabular}

Suppressor F: TGTCTTTCAAATCTGCCTCC

of IKBKE 1 R: GGCTTGGCAACAACTTTC

GAPDH F: ACCCAGAAGACTGTGGATGG

125 R: TTCAGCTCAGGGATGACCTT

F, forward; R, reverse; GAPDH, glyceraldehyde 3-phosphate dehydrogenase.

Table II. RNA extraction from HCT-8 and HCT-8/V cells.

\begin{tabular}{lcc}
\hline Sample & RNA concentration $(\mathrm{ng} / \mu \mathrm{l})$ & $\mathrm{OD}_{260 / 280}$ \\
\hline HCT-8 & 763 & 1.96 \\
HCT-8/V & 245 & 2.10 \\
\hline
\end{tabular}

HCT-8/V, vincristine-resistant HCT-8; OD $_{260 / 280}$, ratio of the optical density at 260 and $280 \mathrm{~nm}$.

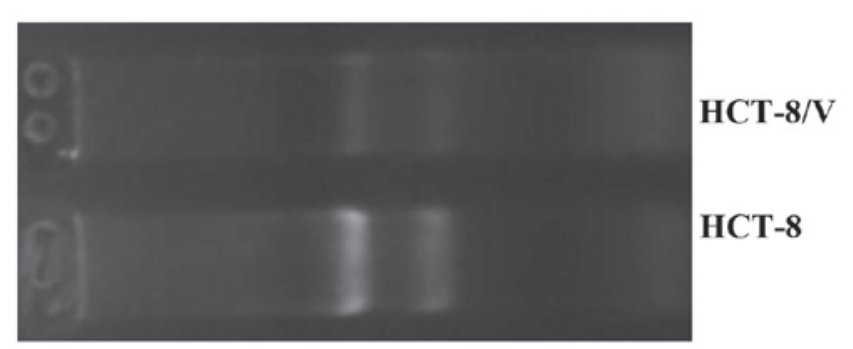

Figure 1. RNA extraction from HCT-8 and HCT-8/V cells. HCT-8/V, vincristine-resistant HCT-8.

\section{Results}

RNA extraction. RNA extraction is an important step in RT-PCR, and the quality of extracted RNA indicates the success of PCR. RNA extracted in the current study exhibited complete bands using electrophoresis (Fig. 1). The concentrations of RNA for HCT- 8 and HCT-8/V were 763 and $245 \mathrm{ng} / \mu \mathrm{l}$, respectively, and the ratios of the optical density at 260 and $280 \mathrm{~nm}$ were 1.96 and 2.10 , respectively (Table II). These findings demonstrate that the extracted RNA was high quality and could be used to perform RT-qPCR.

RT-qPCR. Expression of IKBKE 1 in the HCT-8/V colon cancer cells was detected using RT-qPCR using the extracted RNA and specific PCR primers. The amplification curves of $I K B K E 1$ and GAPDH were observed to be ' $\mathrm{S}$ ' type and the melting curves were characterized by a single curve, indicating effective amplification (Fig. 2A and B). Relative expression of IKBKE 1 in HCT-8 sensitive cells $(1.985 \pm 0.1050)$ was significantly higher than that in the HCT-8/V cells $(1.000 \pm 0.0500)$ [1.985-fold $(\mathrm{P}<0.05$; Fig. 2C and D)]. 
A

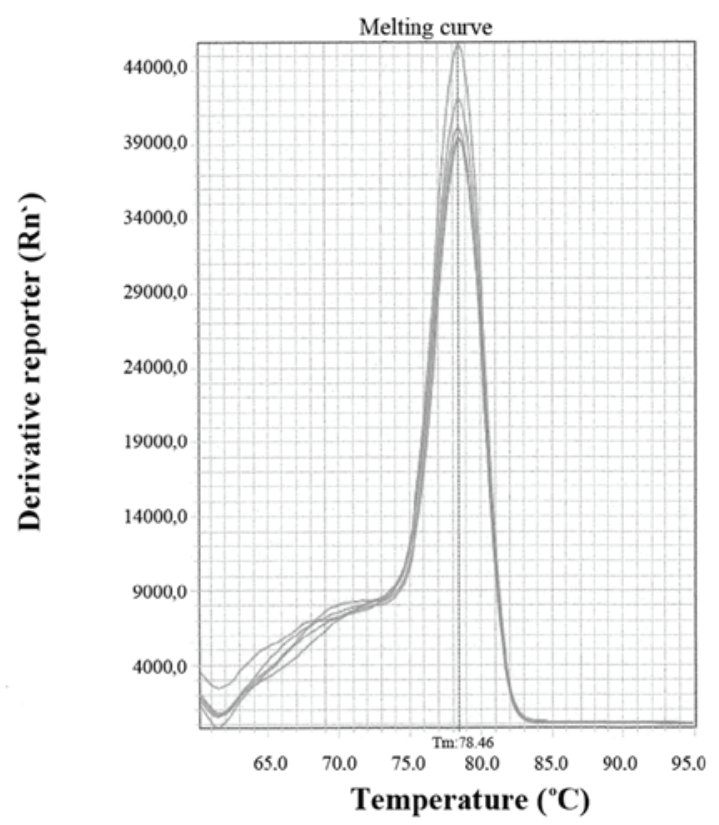

C

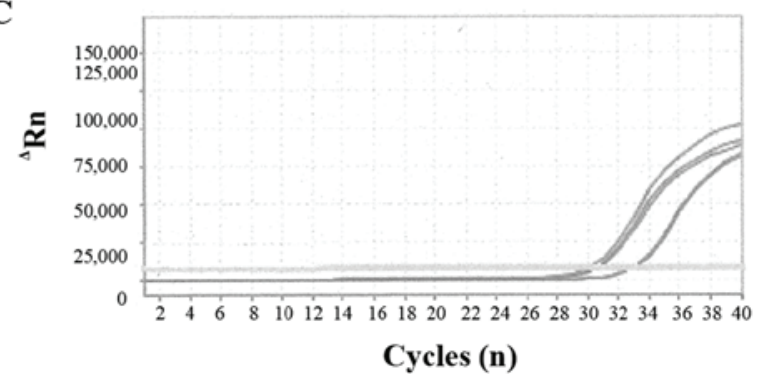

B

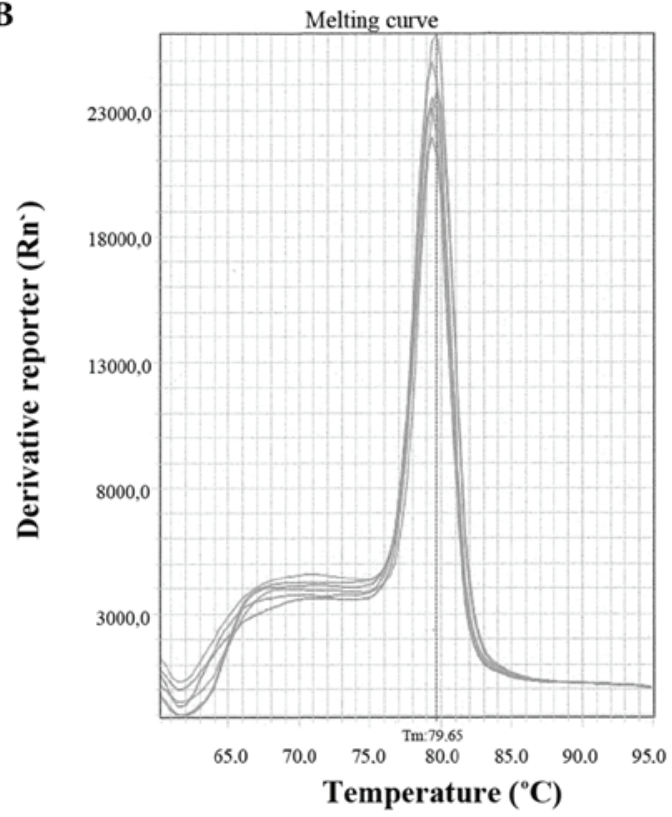

D

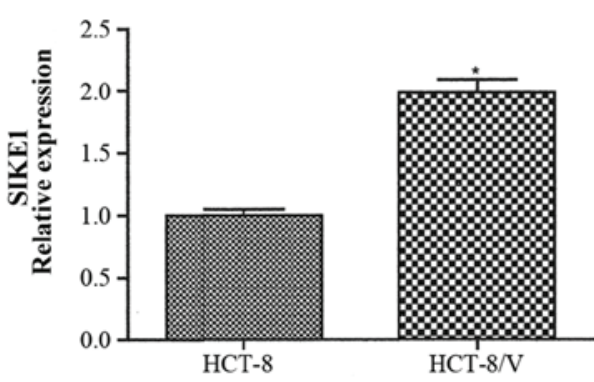

Figure 2. IKBKE 1 expression in HCT- 8 and HCT- $8 / \mathrm{V}$ cells was detected by reverse transcription-quantitative polymerase chain reaction. $\beta$-actin served as a loading control. Melting curves for (A) IKBKE 1 and (B) glyceraldehyde-3-phosphate dehydrogenase. (C) Amplification plot IKBKE 1. (D) Analysis of IKBKE 1 expression. "P<0.05 vs. HCT-8. IKBKE 1, suppressor of IKBKE 1; HCT-8/V, vincristine-resistant HCT-8; Rn, fluorescence of the SYBR-Green reporter dye; $\Delta \mathrm{Rn}$, baseline-corrected $\mathrm{Rn}$; $\mathrm{Rn}$ ', first derivative of $\mathrm{Rn}$; $\mathrm{Tm}$, melting temperature.

A

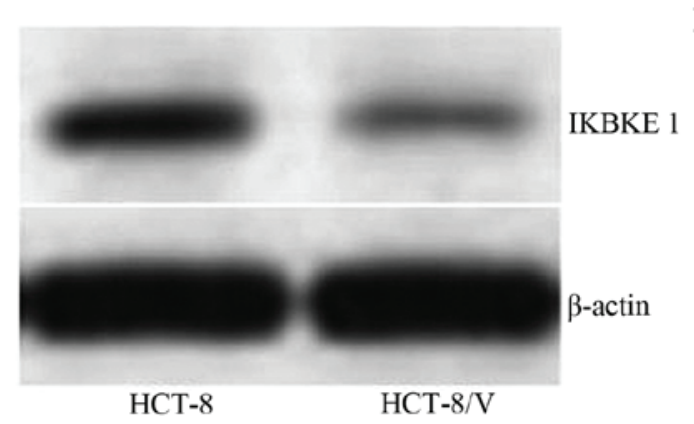

B

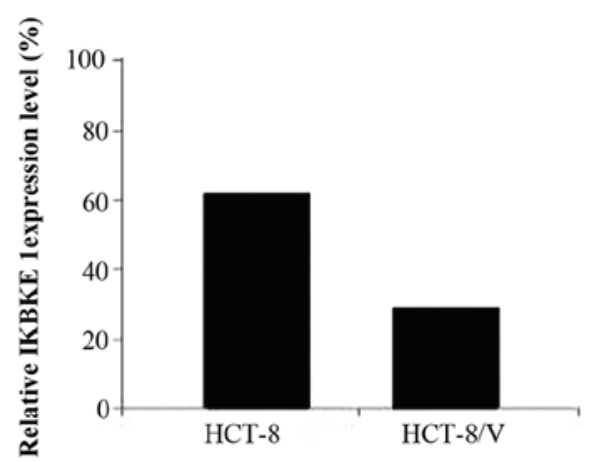

Figure 3. IKBKE 1 expression from HCT-8 and HCT-8/V was detected by (A) western blotting and $\beta$-actin served as a loading control. (B) Relative IKBKE 1 expression level of HCT-8 and HCT-8/V. IKBKE 1, suppressor of IKBKE 1; HCT-8/V, vincristine-resistant HCT-8.

Western blot analysis. The total protein extracted from HCT-8 and HCT-8/V cells was used to estimate relative expression levels after correction using the internal reference ( $\beta$-actin). The expression level of IKBKE 1 in the HCT-8/V cells was significantly higher than that in the HCT-8 cells $(\mathrm{P}<0.05$; Fig. 3). The mean expression level was $0.6233 \pm 0.3654$ for HCT cells, and was 2.13 -fold higher in the HCT-8/V cells than in the HCT-8 cells.

\section{Discussion}

VCR is widely administered to clinically treat certain cancers, including leukemia and lung cancer; however, tumor cells may develop drug resistance (14-17). The resistance mechanism of VCR is complex and involves numerou molecules, such as insulin like growth factor binding protein 7 , multidrug resistance protein 1, miRNAs, and long non-coding RNA $(11,18-23)$. 
A previous study demonstrated that IKBKE 1 in VCR-resistant colon cancer cell lines was significantly increased by $>14$-fold compared with in non-resistant cells (17). Consistent with this result, the present study identified that IKBKE 1 expression in the VCR-resistant cells was significantly higher than in the non-resistant cells using RT-qPCR and western blotting. IKBKE 1 is a target of miR-146a, which contributes to the proliferation of stem cells (10).

In conclusion, gene transcription and translation are two processes involved in gene expression, and certain genes are transcribed to mRNA, but are not translated to proteins (24). The results of the current study prove that the expression of IKBKE 1 is increased in VCR-resistant cells in colon cancer at the mRNA and protein levels. Therefore, the expression of IKBKE 1 has been demonstrated to be associated with VCR drug resistance; however, its function and underlying mechanisms require further investigation.

\section{References}

1. Kim JH: Chemotherapy for colorectal cancer in the elderly. World J Gastroenterol 21: 5158-5166, 2015.

2. Davidson M, Okines AF and Starling N: Current and Future Therapies for Advanced Gastric Cancer. Clin Colorectal Cancer 14: 239-250, 2015.

3. Zhang L, Ngo JA, Wetzel MD and Marchetti D: Heparanase mediates a novel mechanism in lapatinib-resistant brain metastatic breast cancer. Neoplasia 17: 101-113, 2015.

4. Jin AH and Wei ZL: Molecular mechanism of increased sensitivity of cisplatin to ovarian cancer by inhibition of microRNA-23a expression. Int J Clin Exp Med 8: 13329-13334, 2015.

5. Wu Z, Zhang Z, Ge X, Lin Y, Dai C, Chang J, Liu X, Geng R, Wang C, Chen H, et al: Identification of short-form RON as a novel intrinsic resistance mechanism for anti-MET therapy in MET-positive gastric cancer. Oncotarget 6: 40519-40534, 2015.

6. Ho CM, Huang CJ, Huang SH, Chang SF and Cheng WF: Demethylation of HIN-1 reverses paclitaxel-resistance of ovarian clear cell carcinoma through the AKT-mTOR signaling pathway. BMC Cancer 15: 789, 2015 .

7. Jung SO, Kim SY, Kim JO, Jung SS, Park HS, Moon JY, Kim SM and Lee JE: Promising effects of 3rd line cyclophosphamide, adriamycin and vincristine (CAV) and 4th line ifosfamide and carboplatin chemotherapy in refractory small cell lung cancer. Thorac Cancer 6: 659-663, 2015.

8. Chau TL, Gioia R, Gatot JS, Patrascu F, Carpentier I, Chapelle JP, O'Neill L, Beyaert R, Piette J and Chariot A: Are the IKKs and IKK-related kinases TBK1 and IKK-epsilon similarly activated? Trends Biochem Sci 33: 171-180, 2008.

9. Huang J, Liu T, Xu LG, Chen D, Zhai Z and Shu HB: SIKE is an IKK epsilon/TBK1-associated suppressor of TLR3- and virus-triggered IRF-3 activation pathways. EMBO J 24: 4018-4028, 2005.

10. Hsieh JY, Huang TS, Cheng SM, Lin WS, Tsai TN, Lee OK and Wang HW: miR-146a-5p circuitry uncouples cell proliferation and migration, but not differentiation, in human mesenchymal stem cells. Nucleic Acids Res 41: 9753-9763, 2013.
11. Sun QL, Zhao CP, Wang TY, Hao XB, Wang XY, Zhang X and Li YC: Expression profile analysis of long non-coding RNA associated with vincristine resistance in colon cancer cells by next-generation sequencing. Gene 572: 79-86, 2015.

12. Livak KJ and Schmittgen TD: Analysis of relative gene expression data using real-time quantitative PCR and the $2^{-\Delta \Delta C}$ Method. Methods 25: 402-408, 2001.

13. Dong WH, Wang TY, Wang F and Zhang JH: Simple, time-saving dye staining of proteins for sodium dodecyl sulfate-polyacrylamide gel electrophoresis using Coomassie blue. PLoS One 6: e22394, 2011.

14. Chao MW, Lai MJ, Liou JP, Chang YL, Wang JC, Pan SL and Teng CM: The synergic effect of vincristine and vorinostat in leukemia in vitro and in vivo. J Hematol Oncol 8: 82, 2015.

15. Lewis RS, Fidel J, Dassanayake S, Court MH, Burke NS and Mealey KL: Comparison of chemotherapeutic drug resistance in cells transfected with canine ABCG2 or feline ABCG2. Vet Comp Oncol: Oct 14, 2015 (Epub ahead of print).

16. Xu Y and Qiu L: Nonspecifically enhanced therapeutic effects of vincristine on multidrug-resistant cancers when coencapsulated with quinine in liposomes. Int J Nanomedicine 10: 4225-4237, 2015.

17. Martins A, Sipos P, Dér K, Csábi J, Miklos W, Berger W, Zalatnai A, Amaral L, Molnár J, Szabó-Révész P and Hunyadi A: Ecdysteroids sensitize MDR and non-MDR cancer cell lines to doxorubicin, paclitaxel, and vincristine but tend to protect them from cisplatin. Biomed Res Int 2015: 895360, 2015.

18. Bartram I, Erben U, Ortiz-Tanchez J, Blunert K, Schlee C, Neumann M, Heesch S and Baldus CD: Inhibition of IGF1-R overcomes IGFBP7-induced chemotherapy resistance in T-ALL. BMC Cancer 15: 663, 2015.

19. Tivnan A, Zakaria Z, O'Leary C, Kögel D, Pokorny JL, Sarkaria JN and Prehn JH: Inhibition of multidrug resistance protein 1 (MRP1) improves chemotherapy drug response in primary and recurrent glioblastoma multiforme. Front Neurosci 9: 218, 2015

20. Tsubaki M, Takeda T, Ogawa N, Sakamoto K, Shimaoka H, Fujita A, Itoh $\mathrm{T}$, Imano $\mathrm{M}$, Ishizaka $\mathrm{T}$, Satou $\mathrm{T}$, et al: Overexpression of survivin via activation of ERK1/2, Akt, and $\mathrm{NF}-\kappa \mathrm{B}$ plays a central role in vincristine resistance in multiple myeloma cells. Leuk Res 39: 445-452, 2015.

21. Akbari Moqadam F, Lange-Turenhout EA, Ariës IM, Pieters R and den Boer ML: miR-125b, miR-100 and miR-99a co-regulate vincristine resistance in childhood acute lymphoblastic leukemia. Leuk Res 37: 1315-1321, 2013.

22. Wang TY, Zhang QQ, Zhang X, Sun QL, Zhao CP and Wang XY: The effect of recombinant lentiviral vector encoding miR-145 on human esophageal cancer cells. Tumour Biol 36: 9733-9738, 2015.

23. Xu Y, Xia F, Ma L, Shan J, Shen J, Yang Z, Liu J, Cui Y, Bian X, Bie P, et al: MicroRNA-122 sensitizes HCC cancer cells to adriamycin and vincristine through modulating expression of MDR and inducing cell cycle arrest. Cancer Lett 310: 160-169, 2011.

24. Méndez C, Ahlenstiel CL and Kelleher AD: Post-transcriptional gene silencing, transcriptional gene silencing and human immunodeficiency virus. World J Virol 4: 219-244, 2015. 